\title{
ELMIS RIETSCHELI STEFFAN, 1958 (INSECTA: COLEOPTERA: ELMIDAE) IN CROATIA: FIRST RECORD AND DNA BARCODING
}

\section{Vlatka Mičetić Stankovići,*, Branka Bruvo MaĐarić ${ }^{2, *}$, Manfred A. Jäch ${ }^{3} \&$ Mladen Kučinić ${ }^{4}$}

\author{
${ }^{1}$ Croatian Natural History Museum, Demetrova 1, 10000 Zagreb, Croatia \\ ${ }^{2}$ Ruđer Bošković Institute, Bijenička cesta 54, 10000 Zagreb, Croatia \\ ${ }^{3}$ Natural History Museum Vienna, Burgring 7, 1010 Wien, Austria \\ ${ }^{4}$ University of Zagreb, Faculty of Science, Department of Biology, Rooseveltov trg 6, \\ 10000 Zagreb, Croatia
}

Mičetić Stanković, V., Bruvo Mađarić, B., Jäch, M. A. \& Kučinić, M.: Elmis rietscheli Steffan, 1958 (Insecta: Coleoptera: Elmidae) in Croatia: first record and DNA barcoding. Nat. Croat., Vol. 27, No. 1, 185-194, Zagreb, 2018.

Elmis rietscheli Steffan, 1958 (Coleoptera: Elmidae) is a typical inhabitant of cold springs and small streams in the mountainous areas of Central Europe. Recently, three specimens of E. rietscheli were collected in the source area of the Šumi, a stream flowing from Mt. Ivanščica, northern Croatia. The morphological identification of the specimens was confirmed by DNA barcoding. This is the first record of E. rietscheli from Croatia, and it represents the southernmost record for this species known to date.

Key words: DNA sequencing, COI, faunistics, new record, species, crenal, riffle beetles

Mičetić Stanković, V., Bruvo Mađarić, B., Jäch, M. A. \& Kučinić, M.: Elmis rietscheli Steffan, 1958 (Insecta: Coleoptera: Elmidae) u Hrvatskoj: prvi nalaz i DNA barkodiranje. Nat. Croat., Vol. 27, No. 1, 185-194, Zagreb, 2018.

Tipična srednjoeuropska vrsta vodenog kornjaša iz porodice slapoljuba, Rietschelijev slapoljub, Elmis rietscheli Steffan, 1958 (Coleoptera: Elmidae), naseljava hladne izvore i malene vodotoke u središnjoj Europi. Tri primjerka ove vrste prikupljena su na području planine Ivanščice na izvoru potoka Šumi. DNA barkodiranje potvrdilo je morfološku identifikaciju jedinki. To je prvi nalaz vrste $E$. rietscheli za faunu Hrvatske te predstavlja do sada najjužniju zabilježenu točku rasprostranjenja te vrste.

Ključne riječi: DNA sekvencioniranje, COI, fauna, novi nalaz, vrsta, izvor, slapoljubi

\section{INTRODUCTION}

Although the conservation of biodiversity is nowadays recognised as a key priority, taxonomic and faunistic research, both providing basal information for conservation issues, are still undervalued. Therefore, many insect groups, such as Elmidae, are unfortunately still very poorly studied in Europe.

Elmidae, or riffle beetles, are a water beetle family typical of springs and mountain streams (BRown, 1987; Jäch, 1998; JÄCH et al., 2005; Elliott, 2008; KodAdA et al., 2016).

\footnotetext{
* Vlatka.Micetic-Stankovic@hpm.hr / Tel: 0038514851700 / Fax: 0038514851644
}

** Branka.Bruvo.Madjaric@irb.hr / Tel: 0038514571264 / Fax: 0038514561177 
They are rather small-sized (adults are on average 2-3 mm long) with complex life cycles (Crowson, 1981; Elliott, 2008). They are frequently used as bioindicators for freshwater monitoring, i.e. assessments of ecological functionality and water quality (e.g. Eyre et al., 1993; Richoux, 1994; Elliott, 2008; Brojer et al., 2017).

In an annotated checklist of the Elmidae of Croatia, MičEtić STAnкović et al. (2015) listed 23 species; among these there are six species of the genus Elmis Latreille, 1802: E. aenea (Müller, 1806), E. bosnica (Zaitzev, 1908), E. latreillei Bedel, 1878, E. maugetii Latreille, 1802, E. obscura (Müller, 1806), and E. rioloides (Kuwert, 1890).

DNA barcoding (Hebert et al., 2003) is nowadays commonly used in taxonomic research as a means of species identification. This technique is based on sequencing of the standardized $\sim 650 \mathrm{bp}$ long fragment of the mitochondrial (mt) cytochrome oxidase gene subunit I (COI), which bears high interspecific and low intraspecific variability, thus enabling reliable species identifications (RAtNAsingham \& Hebert, 2013). DNA barcodes were found to be especially useful in cases of morphologically ambiguous or sibling species (see e.g. Fossen et al., 2016; Bilton \& Ribera, 2017; Bilton et al., 2017).

In taxonomic studies on Elmidae, DNA barcoding has been used mostly for assigning immature developmental stages to adults, or in smaller phylogenetic studies, and, in a few cases, also in detecting undescribed species (ČIAmpor \& Ribera, 2006; ČIamporová-Zatovičová et al., 2007; ČIampor \& Čiamporová-Zatovičová, 2008; Čiampor \& Kodada, 2010; Hayashi \& Sota, 2010; Freitag \& Balke, 2011; Curiel \& Morrone, 2012; Freitag, 2013; LAššová et al., 2014; Hayashi et al., 2016; ČIAmpor et al., 2016, 2017; Freitag \& Kodada, 2017). Most of these studies deal with tropical species, while for European Elmidae only a few studies based on DNA data are available (e.g. Hendrich et al., 2015; Jovović et al., 2015; Múrria et al., 2017). For instance, in the Barcode of Life Database (ref. webpage BOLD System v4, accessed on March 25, 2018) there are currently data on 87 species (forming distinct BIN clusters) of Elmidae, but only 23 species sampled from seven European countries are included.

Here we present the first record of Elmis rietscheli Steffan, 1958 from Croatia, confirmed by DNA barcoding.

\section{MATERIAL AND METHODS}

\section{Study area}

Ivanščica is the highest mountain in the north of Croatia, with a maximum elevation of $1061 \mathrm{~m}$ a. s. 1. The mountain stretches in a west-east direction; it is about $30 \mathrm{~km}$ long and $9 \mathrm{~km}$ wide. It forms a natural barrier between the Sava and Drava rivers. It is composed of sedimentary rocks, mineral limestones, sandstones, quartz and schist, and it is considered part of the Dinaric Alps (ČAPLAR, 2008; HerAK, 1960; ŠIMUNić, 1983). The climate is moderate continental with some influence from the Adriatic Sea. The annual precipitation varies between 1000 and $1500 \mathrm{~mm}$ (ZANinović et al., 2008).

\section{Sampling and identification}

The specimens were sampled with a hand net (mesh size: $500 \mu \mathrm{m})$, and stored in 96\% ethyl alcohol. Specimens were examined with an Olympus ZX9 stereo microscope, and photographed with an Olympus Tough TG-5 camera. An inverted microscope Axio 
Observer Z1 was used for genitalia photographs. All specimens are deposited in the Croatian Natural History Museum, Zagreb, Croatia.

\section{DNA extraction, PCR amplification, sequencing and sequence analyses}

Genomic DNA was extracted from whole specimens by a non-destructive method, using GenElute Mammalian Genomic DNA Miniprep kit (Sigma-Aldrich, Germany) according to manufacturer's specifications, and eluted in $50 \mu \mathrm{l}$ of elution buffer.

The standard DNA barcode region (650 bp of 5' part of COI gene) was amplified with the use of universal LCO1490 / HCO2198 primers (Folmer et al., 1994). PCR was conducted in a $15 \mu$ l reaction mixture, containing $1 \times$ Dream Taq $^{\mathrm{TM}}$ reaction buffer with $2 \mathrm{mM} \mathrm{MgCl}_{2}$ (Thermo Scientific), $0.2 \mathrm{mM}$ dNTP mix (Qiagen), $0.5 \mu \mathrm{M}$ of each primer, 0.75 units of DreamTaq polymerase (Thermo Scientific) and $3 \mu$ of eluted DNA. PCR cycling conditions were as follows: initial denaturation at $95^{\circ} \mathrm{C}$ for 2 minutes; 35 cycles of $95^{\circ} \mathrm{C}$ for 45 seconds, annealing at $52^{\circ} \mathrm{C}$ for 45 seconds, elongation at $72^{\circ} \mathrm{C}$ for 45 seconds; final elongation at $72{ }^{\circ} \mathrm{C}$ for 7 minutes. PCR products were checked for quality and quantity on $1 \%$ agarose gel stained with ethidium bromide and purified using Exonuclease I and FastAPTM Thermosensitive Alkaline Phosphatase enzymatic system (ThermoFischer Scientific), according to the manufacturer's specifications.

Bidirectional sequencing of PCR products was carried out at Macrogen Inc. (Amsterdam, Netherlands), using the amplification primers LCO1490 and HCO2198. Sequences were checked, edited and assembled from both directions in programs BioEdit v. 7.2.5 (HALL, 1999) and Geneious 8.1.4 (KeArse et al., 2012), and submitted to BOLD (Ratnasingham \& Hebert, 2007) and GenBank databases. BOLD ID and accession numbers are given in Tab. 1.

Tab. 1. Specimens and sequences used in the analyses. Newly sequenced samples are marked in bold.

\begin{tabular}{|l|l|l|l|l|}
\hline Species name & Country & Sample ID & BOLD sequence ID & GenBank Acc. Nr. \\
\hline Elmis rietscheli & Croatia & ELRIO-B24/CROBB1 & CROBF001-18 & MH368658 \\
\hline & & ELRIO-B25/CROBB2 & CROBF002-18 & MH368659 \\
\hline & Germany & BC ZSM AQU 00290 & FBAQU290-09 & HM422035 \\
\hline Elmis aenea & Croatia & KJ381177 & GBCL23072-15 & KJ381177 \\
\hline & & KJ381175 & GBCL23073-15 & KJ381175 \\
\hline & & KJ381172 & GBCL23074-15 & KJ381172 \\
\hline & & KJ381167 & GBCL23078-15 & KJ381167 \\
\hline & Austria & KJ381159 & GBCL23028-15 & KJ381159 \\
\hline & & KJ381158 & GBCL23029-15 & KJ381158 \\
\hline & Germany & ZFMK-TIS-2522902 & GCOL10027-16 & KU910145 \\
\hline & & BC ZSM AQU 00495 & FBAQU400-10 & HM401301 \\
\hline & & ZFMK-TIS-19747 & GCOL3640-16 & KU910942 \\
\hline & Finland & ZMUO.006128 & COLFF808-13 & KJ965229 \\
\hline & Croatia & KJ381192 & GBCL23067-15 & KJ381192 \\
\hline & & KJ381193 & GBCL23066-15 & KJ381193 \\
\hline & & KJ381189 & GBCL23068-15 & KJ381189 \\
\hline & Austria & KJ381179 & GBCL23027-15 & KJ381179 \\
\hline & & KJ381180 & GBCL23026-15 & KJ381180 \\
\hline & & KJ381181 & GBCL23025-15 & KJ381181 \\
\hline
\end{tabular}




\begin{tabular}{|l|l|l|l|l|}
\hline Species name & Country & Sample ID & BOLD sequence ID & GenBank Acc. Nr. \\
\hline & Germany & BC ZSM AQU 00154 & FBAQU154-09 & HM376183 \\
\hline & & BC ZSM AQU 00500 & FBAQU405-10 & HM401304 \\
\hline & Italy & ZFMK-TIS-7959 & GCOL1005-16 & KU911071 \\
\hline Elmis obscura & Germany & BC ZSM AQU 00499 & FBAQU404-10 & HM401303 \\
\hline & & BCZSMAQU00968 & FBCOG778-12 & KM446204 \\
\hline Elmis latreillei & Germany & BC ZSM AQU 00289 & FBAQU289-09 & HM401281 \\
\hline Elmis maugetii & Austria & KJ381196 & GBCL23023-15 & KJ381196 \\
\hline & & KJ381194 & GBCL23024-15 & KJ381194 \\
\hline & Germany & ZFMK-TIS-2522897 & GCOL10025-16 & KU907029 \\
\hline & & BC ZSM AQU 00498 & FBAQU403-10 & HM401302 \\
\hline & & BC ZSM AQU 00055 & FBAQU055-09 & HM376142 \\
\hline & & BC ZSM AQU 00228 & FBAQU228-09 & HM422008 \\
\hline Riolus subviolaceus & Germany & BCZSMAQU01044 & FBCOG854-12 & KM451547 \\
\hline Limnius opacus & Germany & BC ZSM AQU 00538 & FBAQU443-10 & HM401335 \\
\hline
\end{tabular}

BOLD Identification Engine (accessed March 2018) was used for comparison of DNA barcodes amplified from Elmis rietscheli with the barcode data available in BOLD. The single sequence of E. rietscheli in BOLD was provided by the Barcoding Fauna Bavarica Project in Germany (Hendrich et al., 2015). Sequences of E. rietscheli were aligned with all barcode sequences of Elmis species retrieved from BOLD (Tab. 1), with the addition of two outgroup sequences (Elmidae: Limnius opacus Müller, 1806 and Riolus subviolaceus (Müller, 1817)). Sequences were collapsed to haplotypes in FaBox online toolbox (VILLESEN, 2007); uncorrected p-distances and Kimura 2-parameter distances (K2P) between haplotypes were calculated using MEGA 7.0.25 (KumAR et al., 2016). Neighbour-joining (NJ) tree based on the K2P distance model was calculated in MEGA 7.0.25 (Kumar et al., 2016), and the robustness of the clades was assessed through 1000 bootstrap replicates. The maximum likelihood (ML) tree was constructed on PhyML 3.0 web-server (GuINDON et al., 2010), with automatic model selection by SMS (determined through AIC selection criterion) (LEFORT et al., 2017) and aLRT SH-like support.

\section{RESULTS AND DISCUSSION}

Elmis rietscheli was described comparatively recently. Despite its rather distinctive male genitalia, this species was overlooked for a long time, mainly because of its remarkable external variability (J̈̈сH, 1992). For instance, BERTHÉLEMY (1979: 34) noted that $E$. rietscheli resembles E. maugetii, while Schulte (1989) found the specimens which he had examined more similar to E. latreillei; specimens recorded as E. rietscheli from Romania by IEnişTEA (1974) turned out to belong to E. latreillei (BERTHÉLEMY, 1979: 26). This remarkable external changeability, known also from several other elmid species, may depend, at least to some extent, on the water temperature (see e.g. KNIE, 1978).

Three specimens of Elmis rietscheli were sampled by the first author on Mt. Ivanščica (northern Croatia), in the spring area of the Šumi, a mountain stream with gravel and sand benthos (21.VI.2016, 46¹1'21.7'N 169'16.6”'E, ca. $410 \mathrm{~m}$ a.s.1.) (Figs. 1, 2).

It is the first record of Elmis rietscheli in Croatia. This species was so far recorded from France, Germany, Switzerland, Austria, Italy, Slovenia and Hungary (J̈̈̈H et al., 2016); specimens from Hungary were collected in the Kőszeg Mountains, the eastern- 
most region of the Alps, about $700 \mathrm{~m}$ from the Austrian border (Löккӧs, 2010). This species is typical of mountainous areas, where it prefers the eucrenal, the hypocrenal

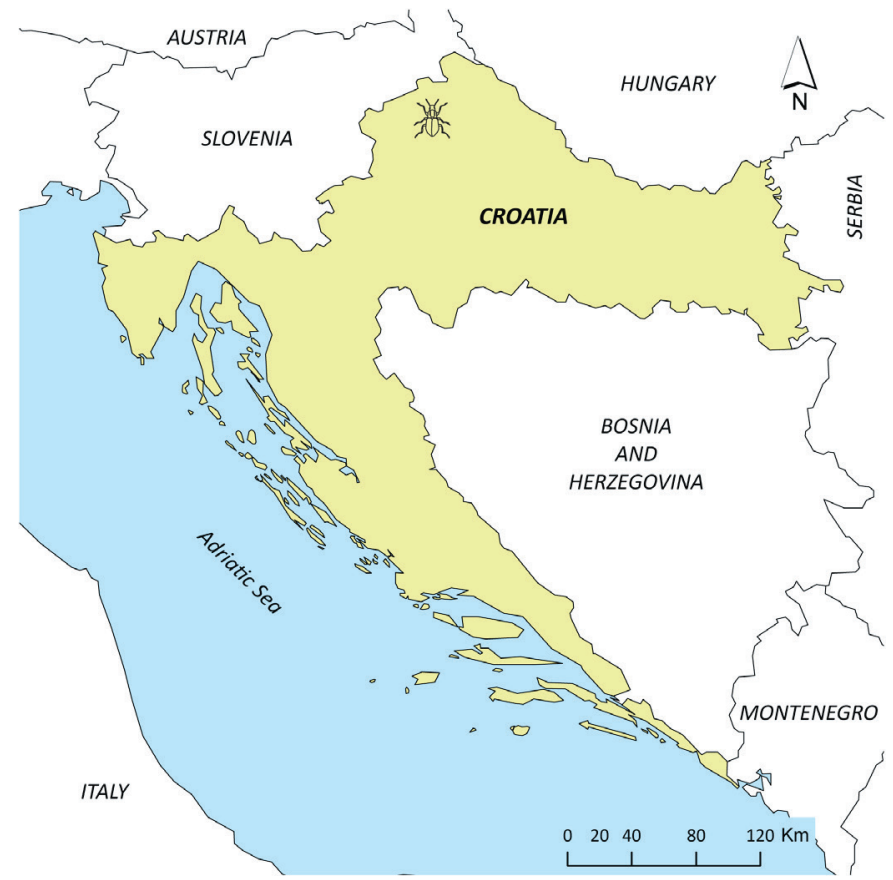

Fig. 1. Position of Mt. Ivanščica in Croatia (beetle symbol).

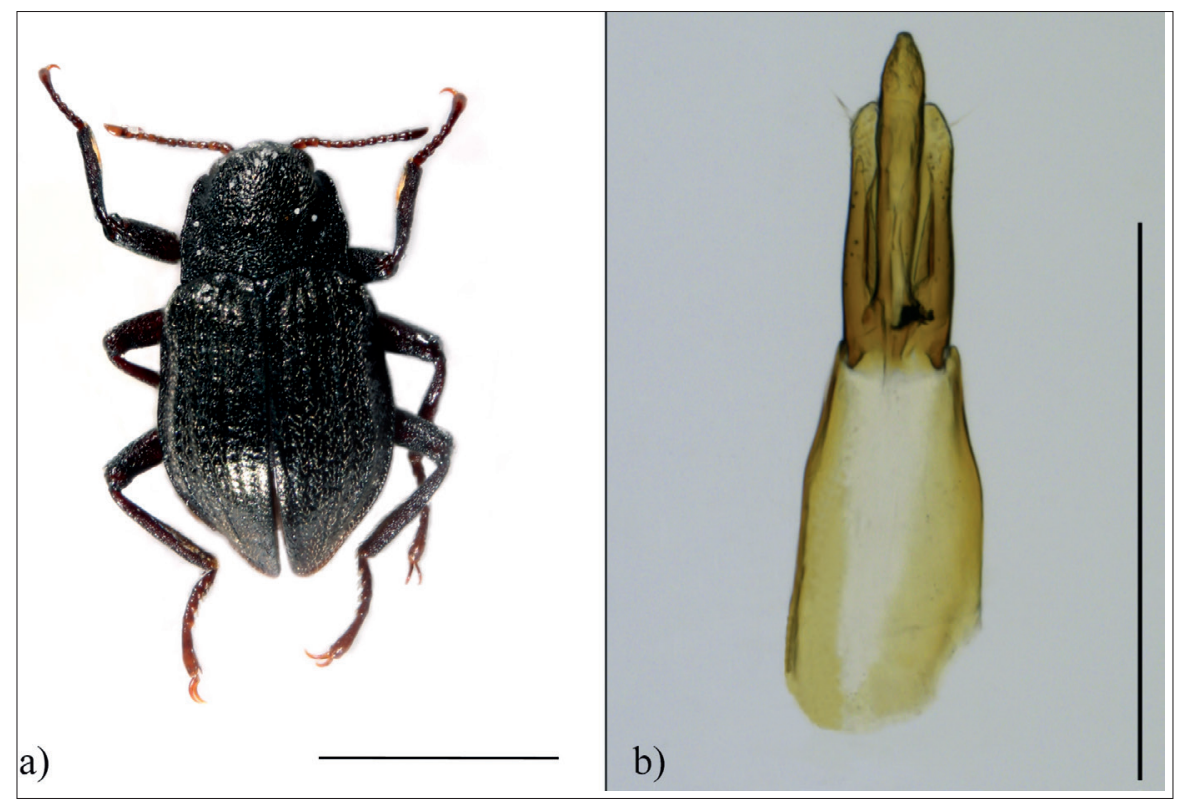

Fig. 2. Elmis rietscheli Steffan, 1958: a) habitus (scale $=1 \mathrm{~mm})$, b) male genitalia $($ scale $=100 \mu \mathrm{m})$. 
and the epirhithral (JÄCH et al., 2005; BROJER et al., 2017); in some parts of the eastern Alps it is very common. Ivanščica Mountain was sometimes considered to be an extension of the Alps (HeraK, 1960; ŠImUnić, 1983).

A molecular analysis confirmed the identification. Two COI haplotypes of the specimens sampled on Mt. Ivanščica have very low sequence divergence with respect to the single E. rietscheli sequence available from BOLD (0.0058 uncorrected p-distance, Tab. 2), which is within the standard intraspecific sequence divergence for COI in beetles (PENTINSAARI et al., 2014). On the other hand, average sequence divergence between haplotypes of different species of Elmis is $11 \%$ (0.043 - 0.134 uncorrected p-distance), which is also within the range of the COI interspecific divergences observed in other groups of beetles.

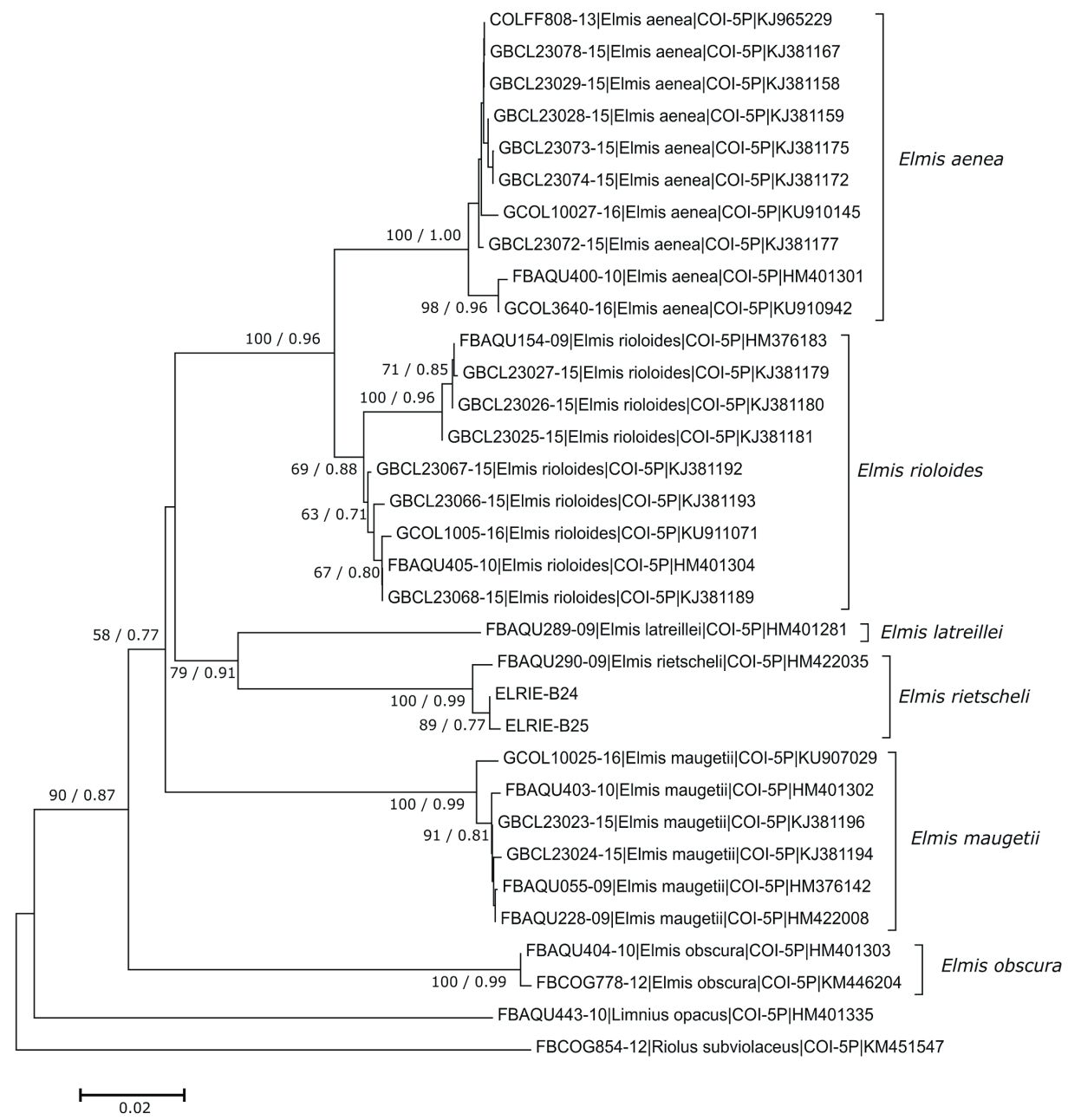

Fig. 3. Neighbour-joining phylogenetic tree constructed by COI sequences of Elmis rietscheli from Croatia and haplotypes of Elmis species from BOLD, based on Kimura-2-parameter distance model. Numbers on branches are NJ bootstrap support values calculated from 1000 bootstrap replicates (above $50 \%$ ) / aLRT-SH like ML support (above 0.7); two sequences of E. rietscheli from Croatia: ELRIE-B24 and ELRIE-B25. 
Tab. 2. Interspecific and intraspecific (bold) uncorrected p-distances calculated for COI sequences of Elmis species.

\begin{tabular}{|l|c|c|c|c|c|c|}
\hline Species name & E. aenea & E. rioloides & E. latreillei & E. rietscheli & E. maugetii & E. obscura \\
\hline E. aenea & $\mathbf{0 . 0 0 4 9}$ & & & & & \\
\hline E. rioloides & 0.0432 & $\mathbf{0 . 0 1 1 7}$ & & & & \\
\hline E. latreillei & 0.1086 & 0.0964 & - & & & \\
\hline E. rietscheli & 0.1103 & 0.0982 & 0.0888 & $\mathbf{0 . 0 0 5 8}$ & & \\
\hline E. mangetii & 0.1148 & 0.1010 & 0.1076 & 0.1194 & $\mathbf{0 . 0 0 3 5}$ & \\
\hline E. obscura & 0.1326 & 0.1182 & 0.1254 & 0.1312 & 0.1339 & $\mathbf{0 . 0 0 1 7}$ \\
\hline
\end{tabular}

This result is further supported by the phylogenetic analysis. The topology of NJ and ML trees was mostly congruent, with only a few exceptions regarding the moderately or weakly supported nodes (Fig. 3). Three E. rietscheli haplotypes group together in a $100 \%$ BS (0.99 aLRT-SH like) supported clade, with E. rietscheli being recovered as sister to E. latreillei.

The record of Elmis rietscheli in Croatia represents the southernmost record for this species. In Croatia it was found in a habitat similar to many of its habitats in Central Europe, confirming its crenal affinities. Further studies should include sampling in other parts of Croatia, with special focus on springs and mountain streams.

\section{ACKNOWLEDGEMENT}

The authors would like to thank Dr. I. Mihoci and Dr. M. Šašić Kljajo for their assistance during the field work. We are grateful to Dr. I. Stanković for the photographs, and for the map (Figs. 1, 2). Special thanks are due to Hrvatske Vode for allowing us to use their equipment for taking the photographs of the habitus and male genitalia. We thank both referees for their careful reading of the MS. The study was supported by Croatian Science Foundation grants IP-2016-06-9988 “DNA barcoding of biodiversity of Croatian fauna" (Project leader: Prof. M. Kučinić) and IP-2014-09-3733 (Project leader: Prof. Đ. Ugarković), and by MZOŠ-HR / MBWFW grant HR 09/2016 (Project leaders: B. Bruvo Mađarić and M.A. Jäch).

Received April 20, 2018

\section{REFERENCES}

BerthéLemy, C., 1979: Elmidae de la région paléarctique occidentale: systématique et répartition (Coleoptera Dryopoidea). Annales de Limnologie 15(1), 1-102.

Bilton, D.T. \& Ribera, I., 2017: A revision of Meladema diving beetles (Coleoptera, Dytiscidae), with the description of a new species from the central Mediterranean based on molecules and morphology. ZooKeys 702, 45-112. doi:10.3897/zookeys.702.14787

Bilton, D.T., Turner, L. \& Foster, G.N., 2017: Frequent discordance between morphology and mitochondrial DNA in a species group of European water beetles (Coleoptera: Dytiscidae). PeerJ 5, e3076. doi:10.7717/peerj.3076

Brojer, M., Jäch, M.A. Kodada, J. \& Moog, O., 2017: COLEOPTERA: Water Beetles s.1. In: Moog, O. \& Hartmann, A. (eds.), Fauna Aquatica Austriaca, 3. Edition 2017. Wien: Federal Ministry of Agriculture, Forestry, Environment and Water Management, 49 pp. Available at: http://www.ecoprof.at/index.php/faunaaquaticaaustriaca.html 
Brown, H.P., 1987: Biology of riffle beetles. Annual Review of Entomology 32, 253-273. doi:10.1146/annurev.en.32.010187.001345

Crowson, R.A., 1981: The biology of the Coleoptera. Academic Press. London, 802 pp.

Curiel, J. \& Morrone, J.J., 2012: Association of larvae and adults of Mexican species of Macrelmis (Coleoptera: Elmidae): A preliminary analysis using DNA sequences. Zootaxa 3361, 56-62. doi:10.5281/ zenodo.182342

ČAPLAR, A., 2008: Planinarski vodič po Hrvatskoj. Bibliotheca geographia Croatica, pp. 186-187. (in Croatian).

Čiampor, F. \& Čiamporová-Zatovičová, Z., 2008: A new species of Hedyselmis Hinton and notes on the phylogeny of the genus (Coleoptera: Elmidae). Zootaxa 1781, 55-62. doi:10.5281/zenodo.182342

Čıampor, F., Čiamporová-Zatovičová, Z. \& KodadA, J., 2017: A new species of Neblinagena Spangler from Kukenán tepui and DNA barcoding of Neblinagena and related genera (Coleoptera: Elmidae). Zootaxa 4286(2), 176-186. doi:10.11646/zootaxa.4286.2.2

ČIAmpor, F. \& KodAdA, J., 2010: Taxonomy of the Oulimnius tuberculatus species group (Coleoptera: Elmidae) based on molecular and morphological data. Zootaxa 2670, 59-68.

Čiampor, F., Laššová, K., Maier, C.A., Čiamporová-Zatovičová, Z. \& Kodada, J., 2016: Phanoceroides Hinton, 1939: Description of new species, morphology of larvae, and revised taxonomic position of the genus (Coleoptera: Elmidae) based on molecular evidence. Zootaxa 4117(2), 277-288. doi:10.11646/ zootaxa.4117.2.9

ČIAmpor, F. \& Ribera, I., 2006: Hedyselmis opis: Description of the larva and its phylogenetic relation to Graphelmis (Coleoptera: Elmidae: Elminae). European Journal of Entomology 103, 627-636. doi:10.14411/eje.2006.084

ČIAmporovÁ-Zatovičová, Z., ČIAmpor, F. \& KodadA, J., 2007: Stenelmis puberula Reitter (Coleoptera: Elmidae) - description of larva and its association with adults, using DNA sequences. Zootaxa 1661, 17-28. doi:10.11646/zootaxa.1661.1.2

Elliotr, J.M., 2008: The ecology of riffle beetles (Coleoptera: Elmidae). Freshwater Biology 1, 189-203. doi:10.1608/FRJ-1.2.4

Eyre, M.D., Pilkington, J.G., Carr, R., McBlane, R.P., Rushton, S.P. \& Foster, G.N., 1993: The runningwater beetles (Coleoptera) of a river catchment in northern England. Hydrobiologia 264, 33-45.

Folmer, O., Black, M., Hoeh, W., Lutz, R. \& Vrijenhoek, R., 1994: DNA primers for amplification of mitochondrial cytochrome c oxidase subunit I from diverse metazoan invertebrates. Molecular Marine Biology and Biotechnology 3, 294-299.

Fossen, E.I., Ekrem, T., Nilsson, A.N. \& Bergsten, J., 2016: Species delimitation in northern European water scavenger beetles of the genus Hydrobius (Coleoptera, Hydrophilidae). ZooKeys 564, 71-120. doi:10.3897/zookeys.564.6558

Freitag, H., 2013: Ancyronyx Erichson, 1847 (Coleoptera, Elmidae) from Mindoro, Philippines, with description of the larvae and two new species using DNA sequences for the assignment of the developmental stages. ZooKeys 321, 35-64. doi:10.3897/zookeys.321.5395

Freitag, H. \& BAlke, M., 2011: Larvae and a new species of Ancyronyx Erichson, 1847 (Insecta, Coleoptera, Elmidae) from Palawan, Philippines, using DNA sequences for the assignment of the developmental stages. ZooKeys 136, 47-82. doi:10.3897/zookeys.321.5395

Freitag, H. \& Kodada, J., 2017: Larvae of Ancyronyx Erichson, 1847 (Insecta: Coleoptera: Elmidae) from Sulawesi, using DNA sequences for the assignment of the larval stages. Zootaxa 4299(1), 121-130. doi:10.11646/zootaxa.4299.1.6

Guindon, S., Dufayard, J.F., Lefort, V., Anisimova, M., Hordijk, W. \& Gascuel, O., 2010: New algorithms and methods to estimate maximum-likelihood phylogenies: assessing the performance of PhyML 3.0. Systematic Biology, 59(3), 307-321. doi:10.1093/sysbio/siq010

HALl, T.A., 1999: BioEdit: a user-friendly biological sequence alignment editor and analysis program for Windows 95/98/NT. Nucleic Acids Symposium Series 41, 95-98.

Hayashi, M., Kamite, Y., Kobayashi, T. \& Sota, T., 2016: Description of larvae of genera Stenelmis, Ordobrevia and Nomuraelmis (Coleoptera: Elmidae: Elminae) of Japan with their molecular taxonomy. Zootaxa 4178(4), 451-480. doi:10.11646/zootaxa.4178.4.1

Hayashi, M. \& Sota, T., 2010: Identification of elmid larvae (Coleoptera: Elmidae) from Sanin District of Honshu, Japan, based on mitochondrial DNA sequences. Entomological Science 13, 417-424. doi:10.1111/j.1479-8298.2010.00404.x 
Hebert, P.D.N., Cywinska, A., Ball, S.L. \& deWAard, J.R., 2003: Biological identifications through DNA barcodes. Proceedings of the Royal Society of London B 270, 313-322. doi:10.1098/rspb.2002.2218

Hendrich, L., Morinière, J., Haszprunar, G., Hebert, P.D.N., Hausmann, A., Köhler, F. \& Balke, M., 2015: A comprehensive DNA barcode database for Central European beetles with a focus on Germany: adding more than 3500 identified species to BOLD. Molecular Ecology Resources 15(4), 795818. doi:10.1111/1755-0998.12354

HeraK, M., 1960: Kreda s ofiolitima u Ivanščici (sjeverozapadna Hrvatska) s geološkom kartom. (Kreide mit Ophiolithen in der Ivanšćica, NW Kroatien). Acta geologica 2(29), 111-120.

IenişteA, M.A., 1974: Die Elmiden Rumäniens. Travaux du Muséum d'Histoire naturelle „Grigore Antipa“ XIV, 209-238.

Jäch, M.A., 1992: 42. Familie: Dryopidae, 42.a Familie: Elmidae, 44.a Familie: Psephenidae, pp. 67-82. In: Lohse, G.A. \& Lucht, W. (eds.), Die Käfer Mitteleuropas XIII (2nd suppl.), Krefeld: Goecke \& Evers.

Jäch, M.A., 1998: Annotated check list of aquatic and riparian/littoral beetle families of the world (Coleoptera), pp. 25-42. In: J̈̈̈H, M.A. \& JI, L. (eds.), Water beetles of China. Wien: Zoologisch-Botanische Gesellschaft in Österreich and Wiener Coleopterologenverein. 371 pp.

Jäch, M.A., Dietrich, F. \& Raunig, B., 2005: Rote Liste der Zwergwasserkäfer (Hydraenidae) und Krallenkäfer (Elmidae) Österreichs (Insecta: Coleoptera), pp. 211-284. In: ZuLKA, K.P. (ed.), Rote Listen gefährdeter Tiere Österreichs. Checklisten, Gefährdungsanalyse, Handlungsbedarf. Part 1: Säugetiere, Vögel, Heuschrecken, Wasserkäfer, Netzflügler, Schnabelfliegen, Tagfalter (Grüne Reihe des Lebensministeriums, Vol. 14/1). Wien: Bundesministerium für Land- und Forstwirtschaft, Umwelt und Wirtschaft, 407 pp.

Jäch, M.A., Kodada, J., Brojer, M., Shepard, W.D. \& Čiampor, F., 2016: Coleoptera: Elmidae and Protelmidae. World Catalogue of Insects, Vol. 14. Leiden: Brill, XXI + 318 pp.

Jovović, L., Bruvo MaĐarić, B., Mičetić Stanković, V., Jäch, M.A. \& Kučinić, M., 2015: Phylogeny and phylogeography of genus Elmis (Coleoptera, Elmidae) in karstic running waters in southeastern Europe, pp. 173-174. In: Klobučar, G., Kopjar, N., Gligora Udovič, M., LuKšA, Ž. \& Jelić, D. (eds.), 12th Croatian Biological Congress with International Participation. Sveti Martin na Muri, Croatia: Croatian Biological Society 1885.

Kearse, M., Moir, R., Wilson, A., Stones-Havas, S., Cheung, M., Sturrock, S., Buxton, S., Cooper, A., Markowitz, S., Duran, C., Thierer, T., Ashton, B., Mentjies, P. \& Drummond, A., 2012: Geneious Basic: an integrated and extendable desktop software platform for the organization and analysis of sequence data. Bioinformatics 28(12), 1647-1649. doi:10.1093/bioinformatics/bts199

KNIE, J., 1978: Untersuchungen an Elmis maugetii var. hungarica var. n. und ihre Abgrenzung gegenüber Elmis maugetii Latreille, 1798 und Elmis maugetii var. megerlei (Duftschmid, 1805) (Coleoptera: Dryopoidea). Folia Entomologica Hungarica (Rovartani Közlemények) (Series Nova) 31(1), 61-67.

KodAda, J., JÄCH, M.A. \& ČIAmpor, F., 2016: 19.2. Elmidae Curtis, 1830, pp. 561-589. In: Beutel, R.G. \& Leschen, R.A.B. (eds.), Handbook of Zoology, Volume IV (Part 38), Coleoptera, Beetles, Volume 1: Morphology and Systematics (Archostemata, Adephaga, Myxophaga, Polyphaga partim), 2 nd ed. Berlin, New York: Walter de Gruyter, XVII + 684 pp.

Kumar, S., Stecher, G. \& Tamura, K., 2016: MEGA7: Molecular evolutionary genetics analysis version 7.0 for bigger datasets. Molecular Biology and Evolution 33(7), 1870-4. doi:10.1093/molbev/msw054

Laššová, K., Čiampor, F. \& ČIAMPorová-Zatovičová, Z., 2014: Two new Larainae species from Guayana region, Venezuela (Coleoptera: Elmidae). Zootaxa 3753(2), 187-195. doi:10.11646/zootaxa.3753.2.8

Lefort, V., Longueville, J.E. \& Gascuel, O., 2017: SMS: smart model selection in PhyML. Molecular Biology and Evolution, 34(9), 2422-2424. doi:10.1093/molbev/msx149

Lő́кӧs, A., 2010: First record of Elmis rietscheli Steffan, 1958 from Hungary (Coleoptera: Elmidae). Folia entomologica hungarica 71, 31-33.

Mičetić Stanković, V., Jäch, M.A. \& Kučınıć, M., 2015: Annotated checklist of Croatian riffle beetles (Insecta: Coleoptera: Elmidae). Natura Croatica 24(1), 93-109. doi:10.20302/NC.2015.24.5

Múrria, C., Bonada, N., Vellend, M., Zamora-Muñoz, C., Alba-Tercedor, J., Elisa Sainz-Cantero, C., Garrido, J., Acosta, R., El Alami, M., Barquín, J., Derka, T., Álvarez-Cabria, M., Sáinz-Bariain, M., Filipe, A.F. \& Vogler, A.P., 2017: Local environment rather than past climate determines community composition of mountain stream macroinvertebrates across Europe. Molecular Ecology 26(21), 6085-6099. doi:10.1111/mec.14346

Pentinsaari, M., Hebert, P.D.N. \& Mutanen, M., 2014: Barcoding beetles: a regional survey of 1872 species reveals high identification success and unusually deep interspecific divergences. PLoS ONE 9(9), e108651. doi:10.1371/journal.pone.0108651 
Ratnasingham, S. \& Hebert, P.D.N., 2007: BOLD: The Barcode of Life Data System (http://www.barcodinglife.org). Molecular Ecology Notes 7, 355-364. doi:10.111/j.1471-8286.2007.01678.x

Ratnasingham, S. \& Hebert, P.D.N., 2013: A DNA-based registry for all animal species: the Barcode Index Number (BIN) system. PLoS ONE 8(8), e66213. doi:10.1371/journal.pone.0066213

Richoux, P., 1994: Theoretical habitat templates, species traits, and species richness: aquatic Coleoptera in the upper Rhône River and its floodplain. Freshwater Biology 31,377-395. doi:10.1111/j.1365-2427.1994. tb01747.x

Schulte, H., 1989: Beiträge zur Ökologie und Taxonomie der Gattung Elmis Latreille (Insecta: Coleoptera, Elmidae) unter besonderer Berücksichtigung niederbayerischer Vorkommen. Lauterbornia 1, 23-37.

Šımunić, A., 1983: Pregled geološke građe sjeverozapadne Hrvatske, pp. 41-50. In: MoHorovičić, A. (ed): Varaždinski zbornik. Zbornik radova sa znanstvenog skupa povodom obilježavanja 800. godišnjice grada. Varaždin, Zagreb: JAZU (in Croatian).

VILLESEN, P., 2007: FaBox: an online toolbox for FASTA sequences. Molecular Ecology Notes 7(6), 965-968. doi:10.1111/j.1471-8286.2007.01821.x

Zaninović, K., Gajić-ČAPKa, M., PerčEc Tadić, M. et al., 2008: Klimatski atlas Hrvatske / Climate atlas of Croatia 1961-1990, 1971-2000. Croatian Meteorological and Hydrological Service, Zagreb, 200 pp. (in Croatian). 